\title{
The Philippines: \\ The Challenges of Moro and Lumad Power-sharing in the Bangsamoro
}

\author{
Jose Mikhail PEREZ
}

\begin{abstract}
Two self-ascribed ethnic groups-Moro and Lumad-are native to Mindanao in the southern Philippines. Both groups share a common history of oppression from Western colonialism, Christian resettlement, and capitalist interests where the former has waged a more organized insurgency against the Philippine government in the late twentieth century. Due to the political superiority of the Moros, the Lumads are often left marginalized in the various peace processes in Mindanao due to their accommodation to the Moro's call for the creation of anautonomous region under an internal power-sharing agreement. This form of double marginalization against the Lumad promotes a sense of internal colonialism where such arrangements are only left between the Bangsamoro regional government and the Philippine national government, thereby forcing the latter to accommodate to Moro interests. Analyzing the text of the recent peace agreements between the Republic of the Philippines and the Moro Islamic Liberation Front (GRP-MILF), the article attempts to understand the conflict dynamics between Moros and Lumads under power-sharing and power-dividing measures. The article concludes that consociationalismin ethnically divided societies often lead to more ethnic cleavages if done haphazardly to favor certain interests while leaving ethnic minorities at a disadvantage.
\end{abstract}

Keywords: Moro, Lumad, Mindanao, Bangsamoro, consociationalism, identity politics.

\section{Introduction}

In the longue durée, the people of Mindanao in the southern Philippines have suffered the most due to armed conflict for the past three decades. According to Lara and Champain (2009), the conflict in Mindanao has resulted in 120,000 casualties and the displacement of almost two million people. At present, there are existing agreements
Jose Mikhail PEREZ

Department of Political Science, University of the Philippines Diliman, Philippines

E-mail: jfperez1@up.edu.ph

Conflict Studies Quarterly

Issue 35, April 2021, pp. 70-88

DOI: $10.24193 /$ csq.35.5

Published First Online: 05 April /2021 
between the Government of the Philippines (GRP) and the Moro National Liberation Front (MNLF) in 1996 and the Moro Islamic Liberation Front (MILF) in 2014 that aimed for power-sharing between the Christian-dominated national government in Manila and the Muslim-dominated Bangsamoro regional government. However, both agreements have been failing to sustain the peace due to constant distrust among ethnic groups as a consequence of internal power sharing between the dominant Muslim Moros and the "inferior" indigenous ethnic groups. At present, Mindanao has been the most underdeveloped island group in in the Philippines where absolute poverty is at $45 \%$ compared to the national average of 36\% (Philippine Human Development Report, 2005). Despite the autonomous status of the newly created Bangsamoro Autonomous Region in Muslim Mindanao (BARMM) in 2019, the future of Mindanao still remains unclear with some violence breaking out between government and Moroarmed groups.

Historically speaking, Mindanao has followed a different historical trajectory than the rest of the Philippines. Early encounters with Islam were documented between Arab traders and the natives of western and central Mindanao (Majul, 1973). The indigenous people who converted to Islam, known collectively as the Moros, were able to create a distinct political, economic, and cultural heritage from the rest of the Philippines with the establishment of Islamic sultanates in Sulu and Maguindanao in the sixteenth century. However, the creation of a Filipino nation-state that aimed to unify the entire archipelago under Spanish and American colonialism have marginalized them in mainstream society. Furthermore, other factors such as the mass migration of Christian settlers in Mindanao, land conflicts, and the politics of exclusion promoted by the Philippine government after independence have triggered interethnic violence between Christian Filipinos and Muslim Moros throughout the twentieth century (Abinales \& Amoroso, 2005; Coronel-Ferrer, 2013). This has forced the Moros to pursue an armed insurgency in liberating all Filipino Muslims and their claimed homeland known as the Bangsamoro or 'the land of the Moros'.

On the other hand, the non-Moro indigenous people in Mindanao have also been excluded and marginalized in Philippine mainstream society. They have received less attention from scholars and government officials due to their political inferiority from the Moros. These indigenous people, known collectively as the Lumads, have largely been invisible in various political negotiations over their homeland in Mindanao. They have also been regarded as 'second-class minorities' in the various peace negotiations between the Philippine government and the Moro armed groups due to the fact that the Lumads represent a territorially dispersed indigenous minority group with small populations in a disputed territory (Barter, 2015). This form of double marginalization reflects the politics of exclusion due to the dominance of the Moroethnic groups in the Bangsamoro struggle (Alamon, 2017; Barter, 2015; Paredes, 2015).

At present, the current political structure of the Bangsamoro regional government contains some, if not all, of the following characteristics: (1) autonomous executive and 
legislative powers in the regional level; (2) multipledecision-making bodies in the local level where different ethnic identities are represented at various decision-making levels; and (3) the presence of indigenous peoples in the decision-making policies of the regional government (Coronel-Ferrer, 2012). Despite these recent developments, problems such as bureaucratic inefficiency, the dominance of some ethnic groups in regional governance, and weak institutions on tax collection and state-building continue to plague Muslim Mindanao ever since it was created (Abinales \& Amoroso, 2005; Buendia, 2005; Coronel-Ferrer, 2012). This creates doubt as to whether the existing power-sharing arrangements are sustainable in keeping the peace among previously hostile ethnic groups.

\section{Research Question}

The article argues on the question Does the clash between various ethnic identities within the Bangsamoro power-sharing regime cause the resurgence of identity-based conflict in Mindanao? The article initially rests on the assumption that previously hostile ethnic groups are more likely to engage in interethnic violence during peace transitions. This premise is based on the various arguments that the settlement of peace agreements in ethnically diverse societies are more likely to experience more cycles of violence during peace transitions.(Snyder, 2000; Gurr, 2002; Coakley, 2009; Perez, 2020).

This article is divided into several parts. The first part attempts to provide a brief review of the existing literature on ethnicity and nationalism and relate it to the ongoing Mindanao conflict. Next, the article lays down the scope and specific limitations in order to narrow down the discussion by arguing on the fragility of the internal power-sharing in the Bangsamoro as an independent variable is the one causing the identity-based conflict between the Moros and Lumads which is then considered as the dependent variable.

Afterwards, the article will provide a brief historical background of the Moro and Lumad struggles as two distinct ethnic groups and how are they intertwined in the larger Mindanao question. Next, we then analyze the exclusionary politics promoted by both groups in the context of the newlycreated BARMM. This exclusionary politics between ethnic groups is often problematized by various scholars when studying peace agreements in deeply divided societies (Ljiphart, 1977; Horowitz, 1985; McGarry \& 0'Leary, 1993; Reilly, 2001).

The next part shall explain the existing power-sharing and power-dividing measures between the Moros and Lumads in the BARMM. Due to the lack of genuine representation of indigenous groups in the regional government of Muslim Mindanao, we then argue on the effects of the fragile peace agreement in Mindanao to the various Moro and Lumad minorities and if there are existing concerns that are still overlooked. Finally, we look at the challenges faced by various minorities in both ethnic groups in the context of the future of the Bangsamoro as a self-governing region. A conclusion will then summarize the arguments in the article. 


\section{Ethnicity, nationalism, and power-sharing: a conceptual framework}

Throughout the study, the primary framework that was used is based on two important concepts in the study of identity politics: ethnicity and nationalism. Despite several attempts by various scholars to provide a clear-cut definition, there has never been a consensus for a common definition on both concepts. Young (2003) argues that the problem in fully defining the two concepts lie on the fact that both concepts are not identical since the primary distinction between the two lies in the nature of the political claims that an ethnic group promotes. Summarizing his thoughts, he argues that not all nationalist claims are ethnic since only a minority of ethnic groups often elevate their demand for sovereignty. Connor (1994) uses the term 'ethnonationalism' as an assertion made by various ethnic groups to create a nation-state as highest aspiration of all ethnic groups to assert their identity (Hannum, 2001).

For this study, ethnicity is loosely defined as an identity based on common descent (Walker, 1994 as cited in Wolff, 2006). Horowitz (1985) suggests that ethnicity in ethnic conflicts operate in political terms such as voting patterns and power-sharing arrangements where groups with the same ethnolinguistic groups, such as in the case of Mindanao, vote for their fellow ethnic groups in order to secure power. This can cause grievances on defeated ethnic groups that lead to intergroup violence if left unchecked. At present, the Moros comprise only comprise a minority in the entire Philippine population which is around 5-6\% (Coronel-Ferrer, 2012).

On the other hand, nationalism is defined as an ideology that puts the nation-state first, before all other forms of social or political organization (Wolff, 2006). Anderson (2006) explains that nationalism is operated in terms of an 'imagined community' where people of the same ethnic, linguistic, or religious history espouse a common identity as manifested in the creation of a nation-state. In the case of Mindanao, a Moro homeland is often espoused by various Moro groups in their insurgency against the Philippine government. It is for this reason that Smith (2004) uses the concept "ethnie" where nation-states are actually created based on the pre-existence of a dominant ethnic group, a named human community connected to a homeland, possessing common myths of ancestry, shared memories, one or more elements of shared culture, and a measure of solidarity, at least among the elites.

The application of ethnie in contemporary times is best explained by Snyder (2000) who argues that the presence of elite-dominated regimes in ethnically divided states provide a fertile ground for political elites to harness political energies against other ethnic groups that eventually create a security dilemma. A common pattern often observed in heterogeneous societies is that it usually starts when nationalist elites argue that ethnic minorities and other political opponents should be excluded from political 
participation, alleging them that they lack the credentials of being a proper citizen or their alliance to foreign powers (Snyder, 2000). Eventually, these elites create madeup grievances for ethnic groups to use arms and violence in addressing the problem of nation-building.

Throughout most cases, most ethnic elites use religion or language as a primary source for their nationalist agenda. Fox (2004) argues that religion has played a major influence in the rise of ethnic conflicts. Using the Minorites at Risk (MAR) and State Failure (SF) datasets from 1945-2001, the study explains that religion played an important role in aggravating conflicts, especially in the 1980s-1990s. Furthermore, Collier and Hoeffler's (2004) results also confirmed that the recent rise of intrastate conflicts could be attributed to grievance-based conflicts between armed ethnic groups where more than a quarter of these conflicts (28\%) or 22 out of the 79 conflicts have occurred after the Cold War (1989-1999).

Religion has predominantly shaped the aspirations of Moro groups that ultimately aim for secession from the Filipino nation-state. The fall of the Marcos dictatorship has elevated the Moro's plea for regional autonomy through the conduct of a referendum. However, extremist groups within the Moro independence movement have challenged the existing leadership by creating an armed movement that wanted independence (Frake, 1998). The ethnic fragmentation within the Moro secessionist movements between the Maguindanao, Maranao, and Tausug ethnolinguistic groups have only exacerbated already existing divisions in the Bangsamoro movement despite the signing of peace agreements between the national government and separatist groups (Horowitz, 1985). Additionally, this ethno-religious division between the MNLF-MILF has forced the latter's struggle to continue for almost three decades until the signing of a powersharing agreement with the Philippine government in 2014.

Another important variable in this study is the fragility of the power-sharing framework in the democratization of heterogeneous societies. Most of the time, these societies are a product of decades of civil war, revolutions, or coup d'états. Consociationalism approaches often aim to address conflicting communities as the basic blocks of political engagement by institutionalizing them as separate entities within a power-sharing framework (O’Flynn \& Russell, 2005).

Much of the literature in consociationalism and power-sharing is based on the work of Ljiphart (1977) and more recently with McGarry \& O'Leary (2004)where it is based on the assumption that the best way to deal with ethnic divisions at least in the first instance is by taking division seriously. Using the case of the Netherlands, Ljiphart (1977) makes his claim that such approach can be successful over time when power brokers accept the differences between various groups in order to build a just and peaceful democracy for all previously disenfranchised groups. 
On the other hand, scholars like Horowitz (1985) and more recently Reilly (2001), argue for the opposite. According to them, power-sharing and consociationalism only deepens the divisions between ethnic groups who are now forced to sign a peace agreement that will settle their conflicts once and for all. The institutionalization of these agreements only create the impression that these previously hostile groups are now a monolithic whole, instead of treating them as separate ethnic groups with different heritages and identities.

For this study, the article has applied the latter's arguments (Horowitz, 1985; Reilly, 2001) as its framework in understanding the power-sharing framework between the Moros and Lumads in Mindanao. The primary reason why the article primarily uses Horowitz's (1985) arguments on power-sharing is based on two reasons: (1) the arguments posited by both scholars capture the current state of both ethnic groups in Mindanao where unequal relations have been promoted by both groups; and finally (2) the current consociationalism framework promoted by most peace negotiators in the recent peace agreements in Mindanao only deepen the divisions between the two self-ascribed ethnic groups, whether it be on ethnic, regional or religious terms. This will be further discussed in the discussion part of this article.

\section{Scope and Limitations}

To further understand the power-sharing arrangements in the Bangsamoro, the study focus on the post-conflict status of the BARMM after the various peace agreements between the GRP and the MILF leadership in 2014. The study made preliminary explanations on the factors that exacerbate the fragile peace arrangements between the Moros and Lumads in Mindanao.

As a primary limitation, the study will limit its discussion tothe challenges between two indigenous ethnic groups in Mindanao - the Moro and Lumad, while also considering the fact that both self-ascribed ethnic groups are also composed of different ethnolinguistic groups. Overall, the study attempts to understand our knowledge on why ethnic identities are at the 'heart' of the Bangsamoro struggle and the Mindanao conflict in general. Also, the article does not include discussion on the other peace agreements in Mindanao such as the 1976 Tripoli Agreement between the GRP and the MNLF. Since there are also divisions between ethnic groups within the Moro and Lumad identities due to its self-ascription, the study only analyzes the conflict dynamics between the two groups in the recent $\mathrm{CAB}$ negotiations from 2014 onwards.

Moreover, the study acknowledges that the terms Moro and Lumad are self-ascribed identities which means that not all Muslim ethnic groups in Mindanao consider themselves as Moro and not all non-Moro ethnic groups in Mindanao consider themselves as Lumad. Hence, Spivak's (1999) notion of strategic essentialism is also viewed as a 
primary limitation where both Moro and Lumad identities are considered self-ascribed labels composed of different ethnic groups belonging to either group.

\section{Indigenous Moros and Lumads: an intertwined history}

The Lumads and Moros represent two distinct types of ethnic minorities in the Philippines. Despite their indigeneity to Mindanao, the Moros have rejected the 'indigenous' label due to its political designation (Paredes, 2015). The term "indigenous peoples" refers to small-scale tribal minorities in the highlands, which the Moros reject due to their distinct history of establishing sultanates in Mindanao. Instead, they consider themselves at par with the Philippine government since they have formed an armed insurgency to voice out their grievances against the central government. It is only the Lumads who are considered as indigenous to Mindanao since most of them have sought refuge in the highlands when outsiders have established settlements in the Mindanao lowlands (Tebteba Foundation, 2011).

As mentioned earlier, the Moros comprise only 20\% of the population in Mindanao and roughly $5-12 \%$ of the total Philippine population (Coronel-Ferrer, 2012). They have collectively called themselves 'Moro' as derived from the Spanish derogatory term for the Muslims in Spain in order to rally on their fellow Muslims to join their struggle against to what they perceive as Filipino colonialism and oppression. This self-ascribed identity gained popularity when the Muslim Independence Movement (MIM) in the 1970s when Moro elites used the term as a collective identity for all Muslim Filipinos who sought to liberate themselves from Christian oppression and discrimination. At present, the Moros are the overwhelming majority in the BARMM's five provinces and Cotabato City where they are divided into 13 ethno-linguistic groups (Coronel-Ferrer, 2012).

From the various Moro ethnic groups, there are three dominant ethnic groups that comprise at least 66\% of the Moro population (Coronel-Ferrer, 2012). These three groups are the Tausugin the Sulu peninsula, Maranao in the Lanao provinces, and the Maguindanao in Maguindanao. Minority Moro groups like the Badjao, Iranun, and Yakan also inhabit in the scattered settlements in the BARMM which make up the remaining percent of the Moro population.

On the other hand, the Lumads also comprise a notable minority in the Bangsamoro population. They have collectively called themselves Lumad derived from the Cebuano word meaning "native to the earth" in order to distinguish themselves from the Moros and the Christian migrants who have settled in Mindanao. This self-ascribed identity was created during the Lumad People's Federation Assembly in Kidapawan, North Cotabato in 1986 as a response to unify the various indigenous peoples in Mindanao to defend and reclaim their ancestral rights (Alamon, 2017). A small number of Lumads inhabit within the Bangsamoro territory with the Teduray from Maguindanao having the largest numbers. Other Lumad groups like the Dulangan Manobo, Lambiangan, 
and the Higaunon in Lanao del Sur also have significant populations in the ARMM (Coronel-Ferrer, 2012). Lumad minorities such as the Blaan and Higaonon are also recognized within the BARMM (Sec. 8, R.A. 11054).

The arrival of Spanish and American colonizers has altered the histories between the two ethnic minorities. With the primary agenda of converting the natives to Christianity, the Spaniards have held anti-Muslim prejudices against the Moros while the Lumads were allowed to retain their indigenous practices and traditions (Paredes, 2015; Alamon, 2017). Upon the arrival of the Americans, the Moros were granted limited autonomy while the Lumads and other indigenous groups in the Philippines were designated as 'wild tribes' and later as 'non-Christian tribes' in order to distinguish them from the Christianized settlers in the lowlands known as the 'Filipinos' (Rodil, 1993).

After Philippine independence was granted in 1946, the national government has carried out the administrative separation of the Moros and the other indigenous peoples in the Philippines. The separation has left the Lumad in a vulnerable position in Mindanao politics where they have suffered discrimination from Christian settlers who have stolen their land through ingenious ways. Alamon (2017) explains how the Lumads were oppressed by the Christian migrants as documented in their oral histories whereby the latter have promised gifts to the former only to present a long list of items supposedly loaned. Eventually, they had no choice but to give up their communal lands in order to repay these loans. Due to extensive Christian migration in the lowlands and clashes with the Moros, the Lumads have become minorities in their own ancestral homeland (Rodil, 1993).

The separation of the Moro and Lumad agendas after the Marcos administration has been evident in the creation of two distinct bureaucratic offices reporting directly to the president. Under the current administrative structure, the National Commission on Muslim Filipinos (NCMF) administers Moro affairs while the National Commission on Indigenous Peoples' (NCIP) administers the concerns of indigenous peoples (Paredes, 2015). The NCIP was created under the 1997 Indigenous Peoples' Rights Act (R.A. 8371) that aimed to secure ancestral lands for various indigenous groups. Unfortunately, the Lumads are rarely considered as equal with the Moros on peace keeping matters in Mindanao despite their consultative status under the 'tri-people approach' in the GPH-MILF peace process (Paredes, 2015). In other words, this double marginalization of a second-class minority is perpetuated by the Philippine state to a people who also have a legitimate place in the future of a Bangsamoro homeland.

In sum, both ethnic groups have deeply intertwined histories and cultural identities rooted in Mindanao. Such narrative is manifested in the legend of the brothers Mamalu and Tabunaway who are the ancestors of both ethnic minorities. According to the legend, it is said that when Tabunaway converted to Islam in the fifteenth century, Mamalu chose to retain his ancestral beliefs and move away to the highlands in the Pulangi 
River. Despite this, both brothers have made a peace pact that their descendants will coexist peacefully and help each other in times of need (Paredes, 2015). Hence, this narrative remains a justification used by various civil society groups in Mindanao in the various peace negotiations on both ethnic groups as descendants of uncolonized peoples in Mindanao.

\section{The politics of ethnic exclusion in the Bangsamoro}

Both the Moros and Lumads consider land as the primary source of their identity. For this reason, land grievances are often the root of most violent conflicts in Mindanao. Alamon (2017) has cited the case of the Manobo Pulangion in Bukidnon who have been deprived of their ancestral land from the encroachment of capitalist interests that eventually destroyed their ancestral lands.

When the American colonizers arrived, the Manobo Pulangion were driven out of their ancestral lands due to their lack of knowledge in the newly enacted land laws that favored the settlers. This trend was carried over when the first Christian settlers from the Visayas have settled in Northern Mindanao after World War II. The settlers have established large plantations in the Bukidnon plateau where the natives had no choice but to exclude themselves from the outside influence in order to escape marginalization and discrimination from the settlers.

On the other hand, the Moros also share this kind of narrative when Christian settlers from the Visayas have settled in Mindanao, thereby outnumbering them in their ancestral lands (Majul, 1973; Quimpo, 2001; Coronel-Ferrer, 2013). The arrival of Christian settlers has led to clashes between the Christian migrants and Moro natives over the distribution of land where the former have received the support of the national government in order to promote state development and quell the Moro rebellions.

This form of conflict can be described as a 'sons of soil' (SOS) conflict where native populations like the Moros eventually take up arms and support the insurgencies against the migrants and the state backing them (Fearon \& Laitin, 2003; Fearon, 2004). Such mechanism was observed in the onset and duration of the Moro insurgency that had lasted for almost three decades. Throughout this period, the Moros have experienced systemic landlessness in favor of the Christian migrants where private lands were acquired under a registration and titling system (Coronel-Ferrer, 2013).

In order to prevent the escalation of the conflict, several agreements were signed in securing relative peace. The various peace agreements eventually led to the creation of a Framework Agreement on the Bangsamoro (FAB). Under the said agreement, the Philippine government is mandated to provide the basic structure of an autonomous government in Muslim Mindanao through the passage of an organic law and the conduct of a two-part plebiscite that will establish the territory of the newly created region. 
Under the new regime, the national government has delegated specific powers to the Bangsamoro regional government whereby an autonomous political entity shall have a ministerial form of government under the new autonomous government (par. $1 \& 2$, sec. I, FAB, 2014). Executive and legislative powers are now delegated to the Bangsamoro government while leaving certain powers to the national government such as foreign policy and defense (par. 2, sec. III, FAB, 2014). In order to address the existing ethnic cleavages, a consociationalism mechanism between the national and Bangsamoro government was institutionalized to foster interethnic cooperation as stipulated in Section III of the FAB. However, such mechanism was never realized since Moro representation in the national level was only left in the Philippine House of Representatives where Moro leaders are only elected to represent their constituents (Coronel-Ferrer, 2012). As of this writing, there are no allocated seats for Moro candidates in the Philippine Senate as well as on various cabinet positions expect for the NCMF.

The annex on power-sharing has proved to be one of the most significant consociationalism mechanisms in Philippine politics. Coronel-Ferrer (2012) suggests that powersharing mechanisms in resource-sharing are necessary to address the ethnic grievances from various Moro groups against the Philippine government. Moreover, this arrangement was institutionalized in order to prevent ethnic cartels from dominating regional politics although these were never successful. The establishment of power-sharing institutions attempted to recognize the role of indigenous people in promoting peace in the Bangsamoro on the basis of recognition of identity (par. 5, sec. I, FAB, 2014). However, it is quite notable that under the various annexes of the FAB, there has been no mention of the Lumad in the creation of the Bangsamoro homeland.

Various scholars have provided criticism on the consociationalism arrangement in the Bangsamoro. One is the overemphasis on intergovernmental relations between the national and the regional government thereby leaving other ethnic groups in the picture (Abinales \& Amoroso, 2005). Based on the language of the FAB, it is the identity of the Bangsamoro people who are recognized in the new autonomous region as stipulated in sec. 5, par. I of the said agreement:

"The Parties recognize Bangsamoro identity. Those who at the time of conquest and colonization were considered natives or original inhabitants of Mindanao and the Sulu archipelago and its adjacent islands including Palawan, and their descendants whether of mixed or full blood shall have the right to identify themselves as Bangsamoro by ascription or self-ascription..."

This provision only provides the destiny of the Moro people. The seeming intention to erase the Lumad narrative is evident since the language of the agreement only emphasizes that the FAB is an agreement addressed to resolve the Moro question in Mindanao. Hence, the creation of the ARMM was intended to allow nominal self-rule for Muslim Filipinos as well as to improve the material well-being of all Moros only (Paredes, 2015). 
On the other hand, the Lumads as are left invisible to the existing power-sharing arrangements, waiting for the Moros to accommodate their claims to their ancestral domain.

Another criticism is the hegemony of clans in Moro politics where ethnic minorities are left on the fringes. According to Lara (2014), the dominance of these clans has exacerbated more violence in Muslim Mindanao due to constant conflicts between clans known as rido. Most Moro leaders are more concerned on their own constituents which leaves the Lumads vulnerable to power politics between the dominant Tausug and Maguindanao in the BARMM leadership. Since the former is known to be politically accommodating to the demands of their Moro brothers, they are often vulnerable to such forms of clan-based violence between Moro groups.

\section{To share or divide power?}

In order to address the existing ethnic tensions, Coronel-Ferrer (2012) has suggested on the viability of power-sharing and power-dividing arrangements. The recognition of the rights of indigenous peoples was enshrined in the succeeding paragraph of the same section mentioned earlier (sec. 5, par. I):

"Spouses and their descendants are classified Bangsamoro. The freedom of choice of other indigenous peoples shall be respected."

It is notable that the mention of indigenous peoples in the FAB is emphasized in the context of the role of the Lumads in the future of the Bangsamoro. However, it only shows an act of tokenism from the Moros to politically recognize the indigenous people due to their political weakness to counter them in regional politics (Barter, 2015). Kaufmann (1996) has described this phenomenon in post-conflict societies where minorities in ethnically divided societies are less probable to wage conflict against dominant ethnic groups. Hence, the Moros are least concerned to the grievances of the Lumad to reclaim their ancestral domains since the nation-building problem itself is left to the Moros to resolve on their own.

As the Bangsamoro peace negotiations with the MILF came to an end in 2014, there was no clear wording on the ancestral rights of the Lumad despite the fact that the consociationalism framework between the national government and the Moro leadership requires it to be enacted. Under the said mechanism, powers to enact certificates of ancestral domain (COAs) are now delegated to the level of the regional government. During the various negotiations in the GRP-MILF peace process, the Lumads are forced to participate to support Moro leadership in order to garner support in protecting their homelands once the new regional government is established. In sum, Paredes (2015) has cited an interview from an IP leader arguing that the MILF have used their political advantage to garner Lumad support on the creation of a Bangsamoro sub-state:

"They [MILF] said that they could only support Lumad ancestral domain in concept only at that point, because the tribes first needed to support the Bangsamoro 
struggle. After a peace settlement with the government, the MILF would support them".

In order to fully understand the dynamics occurring in both groups under a powersharing political structure, we must distinguish between power-sharing and powerdividing mechanisms. Most literature on ethnic conflicts suggest that consociationalism is often used by peace negotiators to address political settlements on ethnic conflicts in order to prevent majority ethnic groups in oppressing local minorities and triggering new mobilizations (Wolff, 2003; Rothschild \& Roeder, 2005; Mehler, 2009; Adam, 2018). Under these new autonomy regimes, the idea of consociationalism attempts to bridge decades-old ethnic grievances by allocating power between ethnic groups in order to sustain the peace.

Coronel-Ferrer (2012) explains that there are two dominant approaches in preventing the conflicts to recur in autonomous regions, which are power-sharing and powerdividing approaches. The first one emphasizes the sharing of governmental powers between majority and minority ethnic groups through the division of power among ethnic, linguistic, or religious groups. On the other hand, the second approach explains how decision-making is allocated to different decision-making bodies by including previously disenfranchised ethnic groups in the decision-making process to avoid ethnic cleavages. Despite the fact that these observations are commonly used at the national level, they can also be applied to sub-national territories such as autonomous regions.

Power-sharing mechanisms are commonly used by conflict negotiators during peace negotiations in order to secure sustainable peace through democratic institutions. Walter (1997) argues on the viability of power-sharing because there is less international commitment to guarantee it. However, most peace agreements around the world have power-sharing elements in minimizing ethnic cleavages that usually end with identity-based violence. Lara and Champain (2009) emphasize on the politics of exclusion fostered by the Philippine state to the Moros is often rooted in the problem where the national government under the internal revenue allotment (IRA) deprives the sharing of wealth to the regional government. In order to correct this grievance, an annex on wealth sharing was included in the FAB where both national and regional government share the revenues of resources found in the Bangsamoro. Hence, these agreements are institutionalized asymmetrically in order to raise the prospect of national unity to the former rebels where political participation and trust are necessary between parties (Coronel-Ferrer, 2012).

On the other hand, power-dividing mechanisms are entrenched in various peace negotiations in order to promote inclusivity to previously disenfranchised groups. However, not all ethnic cleavages are addressed through the institutionalization of multiethnic autonomous regions. Stedman (1997) argues the presence of so-called spoilers as an important barrier to the implementation of peace agreements. In the case of the Mindanao conflict, 
the Lumads bear the brunt of being labelled as such due to their insistence of asserting their homeland within the contested territories. Paredes (2015) cites the instance when the final draft of the Bangsamoro Basic Law (BBL) from in 2014 has been kept tight under secrecy before it was submitted to Congress in order prevent any critique or input by any spoiler. On the various consultations, it was evident that the peace negotiators have dismissed concerns on the future power-sharing arrangements between Lumads and Moros. As documented in one consultation between the national government and the various Lumad leaders in Cotabato City last 6 February 2014, Professor Miriam Coronel-Ferrer, who was then chief negotiator of the national government in the GRP-MILF peace process, did not answer the queries from the Lumads and instead chided them for being ungrateful (Espina \& Testa, 2014, as cited in Paredes, 2015).

It is unfortunate that the issues spelled out by Stedman (1997) on peace processes share the same characteristics with the Lumad and Moro power-sharing in the Bangsamoro. First, spoilers in the peace process are painted out as the 'bad guys' who are stepping out of something that is perceived as good, regardless of what harm it does to particular group interests. Second, spoilers of the peace process may have been supporters of the previous democratizations. Finally, it is also important to note a rebel movement that is accommodated by a peace process and is apparently sticking to the provisions of the peace agreement, may have been the spoiler during earlier reforms.

Using the previous arguments on the place of the Lumads in a Moro-dominated Bangsamoro, the Lumads are framed by the mainstream media as fragmented 'spoilers' by some government officials and evenby GPH-MILF peace process committee itself since they were considered ungrateful and disrespectful to the commitment for longlasting peace in Mindanao (Paredes, 2015). Second, as mentioned earlier, the Lumads have sidelined their interests in order to accommodate the struggle of their Moro brothers in claiming their homeland in order to finally receive several incentives from the Bangsamoro regional government such as positions in the BARMM parliament in compliance to their existing traditions in selecting their official representatives. However, when the Moros have already signed peace agreements with the national government, Lumad grievances are outrightly dismissed since the Bangsamoro question has now evolved as an issue concerning only Muslim Filipinos. Sadly, most Lumads now have no choice but to participate in the peace process without concrete promises on what their future will be. Finally, it is important to note that the MILF were once rebels from the MNLF leadership who have entered into a peace agreement with the Philippine government that led to the creation of the Autonomous Region in Muslim Mindanao (ARMM) in 1998 (Frake, 1998).

Regardless of the recent praise by most observers on the positive prospects of a peaceful Mindanao under the BARMM, one thing remains clear: the constant discrimination against the Lumads by both the national government and the Moro leadership can serve 
as a trigger for future mobilizations if ethnic cleavages are left unaddressed. Despite the uniqueness of a 'tri-peopleapproach' in addressing Mindanao concerns, it only remains in theory than practice because Moros, Lumads, and the Christian settlers still have to prove they can coexist peacefully and harmoniously in a contested territory.

\section{The future of minorities in the Bangsamoro}

Under the consociationalism regime in the Bangsamoro, most Lumads living within the BARMM have already acknowledged the fact that the mention of 'indigenous peoples' in the various peace agreements is already an important development in their struggle for their ancestral domain. The sidelining of the Lumad agenda by the Moro leadership can be considered as a form of legal and cultural invisibility in the future of the Bangsamoro homeland due to the lack of political will from the regional government to include IP concerns in their agenda. Despite the recent provision on reserved seats allocated to the Lumads in the Bangsamoro parliament (sec. 8, R.A. 11054), it remains problematic since most leaders who are elected in the new parliament usually come from the three dominant Moro ethnic groups (Tausug, Maguindanao, and Maranao). As stipulated in the said law:

\section{SEC. 8. Election for Reserved Seats for Non-Moro Indigenous Peoples.}

Notwithstanding the immediately preceding sections, reserved seats for non-Moro indigenous peoples, such as Teduray, Lambangian, Dulangan Manobo, B'laan, and Higaonon, shall adhere to their customary laws and indigenous processes based on the following:

(a) Primacy of customary laws and practices;

(b) Primacy of consensus building;

(c) Acceptability to the community;

(d) Inclusivity and full participation;

(e) Representation of the collective interests and aspirations of non-Moro indigenous peoples;

(f) Sustainability and strengthening of indigenous political structures;

(g) Track record and capability; and

(h) Gender equality."

It is notable that under the new organic law, both the national and regional governments recognize the existence of the five Lumad tribes living within in the Bangsamoro which are the Teduray, Lambiangan, Dulangan Manobo, Blaan, and Higaonon. But in reality, they are still underrepresented in the regional government. In the previous Bangsamoro Transitional Commission (BTC) last 2013, only two Lumads (Froilyn Mendoza and Melanie Ulama) were appointed against an overwhelming Moro majority who have often managed to dismiss IP concerns on their right to ancestral domain (Paredes, 2015). As of this writing, the Bangsamoro parliament has not yet enacted any legislation on 
ancestral domain and indigenous peoples' rights since the R.A. 8371's coverage is only at the national level.

Another concern on the future of minorities the Bangsamoro is the hegemony of dominant Moro ethnic groups against Moro minorities in the BARMM. The dominance of former MILF rebels in the new BTC, mostly from the Maguindanao ethnolinguistic group, proves an important gap in the power-sharing mechanism where dominant ethnic groups tend to dominate ethnic minorities in regional politics. Rothschild \& Roeder (2005) has warned that cohesive ethnic groups tend to dominate and form an ethnic elite cartel, causing weaker and unorganized ethnic groups to become fearful. Hence, smaller, unorganized Moro groups like the Iranunin Maguindanao and North Cotabato and the Sama-Badjao in Tawi-tawi may only adhere to majority rule in order not to be marginalized by the dominant Maguindanao ethnolinguistic group under the new BARMM regime.

Such pattern can be observed in the recent 2019 plebiscite on the creation of the BARMM. An overwhelming "YES" vote was recorded in the Iranun and Yakan dominated provinces of Basilan and Tawi-tawi, when a majority voted to be included in the BARMM. On the other hand, an interesting trend can be inferred where Sulu voted "NO" to the new BARMM government. This can be attributed to the opposition of the Tausug against the threat of a Maguindanao majority in the BARMM government. Despite their opposition to be included in the BARMM, their vote is aggregated with the previous ARMM government where most have voted "YES" to be included in the new Bangsamoro autonomous region.

Table 1. Results of the 2019 Bangsamoro autonomy plebiscite

Summary of Results-On the ratification of the BOL (R.A. 11054) and inclusion to the BARMM

\begin{tabular}{lrr}
\hline \multicolumn{1}{c}{ Province } & For (YES) & \multicolumn{1}{c}{ Against (NO) } \\
\hline Basilan (excluding Isabela City) & $147,598(95.78 \%)$ & $6,496(4.22 \%)$ \\
\hline Lanao del Sur & $503,626(98.08 \%)$ & $9,816(1.91 \%)$ \\
Maguindanao & $433,273(96.44 \%)$ & $15,990(3.56 \%)$ \\
Sulu & $137,630(45.7 \%)$ & $163,526(54.3 \%)$ \\
Tawi-tawi & $143,443(93.84 \%)$ & $9,419(6.16 \%)$ \\
\multicolumn{1}{c}{ TOTAL } & $\mathbf{1 , 5 4 0 , 0 1 7}(\mathbf{8 8 . 5 7 \% )}$ & $\mathbf{1 9 8 , 7 5 0 ( 1 1 . 4 3 \% )}$ \\
\hline
\end{tabular}

Source: Commission on Elections, 2019

Observing from the table, it can be inferred that unless genuine distribution of power will be allocated to all ethnic groups in Mindanao, the consociationalism project that has sustained the peace in the past few decades may deteriorate if political reforms are left unaddressed. Horowitz (1985) has cited the case of the ethnic divisions within the Moro groups as another point of contention in the Bangsamoro. If these issues are dismissed by peace negotiators in negotiating future peace agreements, it only remains 
certain that future power-sharing arrangements will lead to possible identity-based conflicts over time.

To further complicate the future of the Bangsamoro, the Lumad's lack of representation in the various peace negotiations proves that peace might be elusive under the current BARMM government. Paredes (2015) laments on the current dilemma that the Lumads have to face in asserting their distinct cultural identity within an autonomous territory or suffer from formally accommodating to Moro interests and abandon their identity. Thus, this dilemma is best captured by Smith's (1999) earlier claim that conflicting ethnic groups need a special identity that serves the 'need' for communal solidarity and fraternity; for it sharpens boundaries between communities and points up similarities between members and differences with non-members.

\section{Conclusion}

Both Lumads and Moros share a history of oppression and discrimination from Western colonization, Christianization, and capitalist greed. Despite this shared identity, the Moros have yearned to assert their right for self-determination with the creation of a Bangsamoro homeland as the highest aspiration of all ethnic groups to assert their identity.

On the other hand, the Lumads have also waged to defend their identity by asserting their right to their ancestral domain in Mindanao. Due to their indigenous status, they have been sidelined by the national government and the Moro leadership in the various peace negotiations on the future of the Bangsamoro. Worse, most of them have resorted to political accommodation to Moro interests in the hope that their right for ancestral domains will be heard under Moro autonomy. Unfortunately, this has never been the case since most dominant Moro ethnic groups like the Maguindanao and Tausughave often dominated regional politics in the Bangsamoro regional government.

In order to prevent the occurence of identity-based violence between ethnic groups, the recent peace agreement under the FAB in 2014 has strengthened the power-sharing and power-dividing mechanisms in the newlycreated Bangsamoro autonomous government. Under this regime, power-sharing mechanisms such as consociationalism democracy while power-diving mechanisms such as multi-level decision making between ethnic groups are institutionalized. These measures posit that asymmetrical arrangements raise the prospect of national unity along with an inclusive culture that seeks to avoid ethnic cleavages (Coronel-Ferrer, 2012).

On the contrary, the current arrangement in the Bangsamoro regional government also has its fair share of weaknesses. One is the lack of significant Lumad representation in the regional government due to their political inferiority in regional politics. Second is the tendency of dominant Moro ethnic groups to form ethnic cartels that cause political 
uncertainty if they do not follow the spirit of the existing power-sharing arrangements in place. Finally, the exclusion of other Moro minorities causes an important gap that must be addressed if Moro leaders want an inclusive Bangsamoro to all Filipino Muslims.

Analyzing the text of the peace agreements between the GRP-MILF, it can be inferred that Lumad and Moro identities affirm the existing divisions across various ethnic groups in the Bangsamoro. If such identities are left mobilized, then this can trigger newer conflicts in the future. Violence on both sides is possible since these arrangements tend to favor certain interests while leaving other ethnic minorities left outside the national-building process. Hence, it is hoped that under the new Moro leadership, the rights of ethnic minorities will be protected in order to sustain the peace for generations to come.

Generally speaking, the contributions of this study are twofold. For one, the viability of power-sharing arrangements has yet to be tested not only in the Philippines but also on various identity-based conflicts in Southeast Asia and Africa. Second, the study also provides theoretical and practical relevance in filling the gap to understand the Mindanao conflict beyond the discourse of conflict and politics. The study attempts to include the Lumad's plight as well as the other Moro minorities in the Bangsamoro project as a whole.

In conclusion, the study recommends two issues for further study. First, to assess to what extent can power-sharing arrangements genuinely address multi-ethnic societies like Mindanao. Finally, there is a need to unpack the Moro and Lumad ethnic groups as selfascribed collective identities in analyzing the dynamics of the Mindanao conflict. Only then can we genuinely understand the role of identities in the Mindanao question itself.

Acknowledgements. The author would like to thank Noel Christian Moratilla and John Raymond Jison for providing substantial comments in the writing of this paper.

\section{References}

1. Adam, J. (2018). Bringing grievances back: Towards an alternative understanding of the rise of the Moro Islamic Liberation Front in the Philippines. Journal of the Humanities and Social Sciences of Southeast Asia, 174(1), 1-23.

2. Abinales, P., \& Amoroso, D. (2005). State and society in the Philippines. Rowman \& Littlefield Publishers.

3. Alamon, A. (2017). Wars on extinction: Discrimination and the Lumad struggle in Mindanao. Rural Missionaries of the Philippines Northern Mindanao Sub-region.

4. Anderson, B. (2006). Imagined communities: Reflections on the origin and spread of nationalism. Verso.

5. Barter, S. (2015). Second order minorities in Asian secessionist conflicts: problems and prospects. Asian Ethnicity, 16(2), 123-135.

6. Buendia, R. (2005). The state-Moro armed conflict in the Philippines: Unresolved national question or question of governance? Asian Journal of Political Science,13(1),109-138. 
7. Collier, P., \& Hoeffler, A. (2004). Greed and grievance in civil war. Oxford Economic Papers, 56(4), 563-595.

8. Commission on Elections. (2019, January 26). January 21, 2019 Bangsamoro Organic Law Plebiscite, Report No. 2. National Plebiscite Board of Canvassers.

9. Coakley, J. (2009). Comparing ethnic conflicts: Common patters, shared challenges. Nationalism and Ethnic Politics, 15(3-4), 261-279.

10. Connor, W. (1994). Ethnonationalism: The quest for understanding. Princeton University Press.

11. Coronel-Ferrer, M. (2012). To share or divide power? Minorities in autonomous regions, the case of the autonomous region in Muslim Mindanao. Ethnic and Racial Studies, 35(12), 2097-2115.

12. Coronel-Ferrer, M. (2013). Costly wars, elusive peace: Collected essays on the peace processes in the Philippines, 1990-2007. University of the Philippines Press.

13. Fearon, J., \& Laitin, D. (2003). Ethnicity, insurgency and civil war. World Development, $39(2), 99-211$.

14. Fearon, J. (2004). Why dosome civil wars last so much longer than others?. Journal of Peace Research, 41(3), 275-301.

15. Fox, J. (2004). The rise of religious nationalism and conflict: Ethnic conflict and revolutionary wars, 1945-2001. Journal of Peace Research, 41(6), 715-731.

16. Frake, C. (1998). Abu Sayyaff: Displays of violence and the proliferation of contested identities among Philippine Muslims. American Anthropologist, 100(1), 41-51.

17. Gurr, T. (2002). Attaining peace in divided societies: Five principles of emerging doctrine. International Journal on World Peace, 19(2), 27-51.

18. Horowitz, D. (1985). Ethnic groups in conflict. University of California Press.

19. Hannum, H. (2001). Nationalism and International Law. In A. Motyl (Ed.), Encyclopedia of Nationalism (pp. 405-414). Academic Press.

20. Kaufmann, C. (1996). Possible and impossible solutions to ethnic civil wars. International Security, 20(4), 136-175.

21. Lara, F., \& Champain, P. (2009). Inclusive Peace in Mindanao: Revisiting the dynamics of conflict and exclusion. International Alert, 1-23.

22. Lara, F. (2014). Insurgents, clans and states: Political legitimacy and resurgent conflict in Muslim Mindanao, Philippines. Ateneo de Manila University Press.

23. Ljiphart, A. (1977). Democracy in plural societies. Yale University Press.

24. Majul, C. (1973). Muslims in the Philippines. University of the Philippines Press.

25. McGarry, J., \& O'Leary, B. (1993). The politics of ethnic conflict regulation. Routledge.

26. Mehler, A. (2009). Peace and power-sharing in Africa: A not so obvious relationship. African Affairs, 108(432), 453-473.

27. O’Flynn, I., \& Russell, D. (2005). Power-sharing: New challenges for divided societies. Pluto Press.

28. Paredes, 0. (2015). Indigenous vs. native: negotiating the place of the Lumads in the Bangsamoro homeland. Asian Ethnicity, 16(2), 166-185. 
29. Perez, J. (2020, October 26). Making peace in deeply divided societies: The case of Mindanao in the southern Philippines. Small Wars Journal. Retrieved from https:// smallwarsjournal.com/jrnl/art/making-peace-deeply-divided-societies-case-mindan ao-southern-philippines.

30. Philippine Human Development Report (2005). Peace, human security, and human development in the Philippines. Philippine Human Development Report. UNDP, NZAID.

31. Quimpo, N. G. (March/April 2001). Options in the pursuit of a just, comprehensive and stable peace in the Southern Philippines. Asian Survey, 41(2), 271-289.

32. Reilly, B. (2001). Democracy in divided societies: Electoral engineering for conflict management. Cambridge University Press.

33. Regan, P., \& Norton, D. (2005). Greed, grievance, and mobilization in civil wars. Journal of Conflict Resolution, 49(3), 319-336.

34. Rodil, R. (1993). The Lumad and Moro of Mindanao. Minority Rights Group.

35. Rothschild, D., \& Roeder, P. (2005). Dilemmas of state-building in divided societies. In G. Roeder and D. Rothschild (Eds.), Sustainable peace, power and democracy after civil wars (pp. 29-50). Cornell University Press.

36. Snyder, J. (2000). Transitions to Democracy and Rise of Nationalist Conflict. In J. Snyder (Ed.), From voting to violence: Democratization and nationalist conflict (pp. 15-43). W.W. Norton \& Co.

37. Stedman, S. J. (1997). Spoiler problems in peace processes. International Security, 22(2), 5-53.

38. Spivak, G. C. (1999). A critique of postcolonial reason: Toward a history of a vanishing present. Harvard University Press.

39. Smith, A. (1999). Myths and memories of the nation. Oxford University Press.

40. Smith, A. (2004). Nationalism: Theory, ideology and history. Cambridge University Press.

41. Tebteba Foundation. (2011). Understanding the Lumad: A closer look at a misunderstood culture. Valley Printing.

42. Walter, B. (1997). The critical barrier to civil war settlement. International Organization, 51(3), 335-364.

43. Wolff, S. (2003). Conflict management in divided societies: The many uses of territorial self-governance. International Journal on Minority and Group Rights, 20(1), 27-50.

44. Wolff, S. (2006). Ethnic Conflict: A global perspective. Oxford University Press.

45. Young, C. (2003). Explaining the Conflict Potential of Ethnicity. In J. Darby and R. MacGinty (Eds.), Contemporary peacemaking: Conflict, violence and peace processes (pp. 9-18). Palgrave Macmillan. 